\title{
AN ARGUMENT FOR ONE DAY FOLLOW-UP IN CANCER CARE
}

\author{
IVA KIRAC ${ }^{1}$, AMIR IBUKIC ${ }^{2}$, LJILJA STEFANCIC ${ }^{1}$, DORA SERCAR ${ }^{3}$, \\ VESNA VORIH ${ }^{1}$ and DRAGAN MARINIC KOROLIJA ${ }^{1}$ \\ ${ }^{1}$ Department of Surgical Oncology, University Hospital for Tumors, \\ Sestre milosrdnice University Hospital Center, Ilica 197, Zagreb, Croatia; \\ ${ }^{2}$ Department of Surgery, Sestre milosrdnice University Hospital Center, \\ Vinogradska 29, Zagreb, Croatia; \\ ${ }^{3}$ Health Center Zagreb East, Zagreb, Croatia
}

\begin{abstract}
Summary
We wanted to assess the distribution of patients and to quantify the travel expenses for specialists' consultation in cancer care. From 1st to 31st October 2018 specialists consulted 2856 with the malignant disease at University Hospital for Tumors. We looked at rectal cancer (C20) specifically and identified 163 rectal cancer patients. Travel expenses are derived from the following:1,35€ per kilometer for patients outside of the city of Zagreb, as denoted by the county they live in, and minimal public transport fee for the patients residing in Zagreb (2,70€). Cost of their return transport within Zagreb was $313,2 €$ while $21362,16 €$ costed the return transport to and from the hospital from outside of Zagreb. The average cost per patient per visit 132,98€. An estimate for 2856 patients is $379784,22 €$. Transport cost for a patient being consulted on cancer care is a substantial part of not recognized costs in system analysis. The process of assessing travel costs display the area of gravitation toward a cancer center. $36 \%$ of patients were from Zagreb.
\end{abstract}

KEY WORDS: cancer care, transport costs, follow-up

\section{Sažetak}

\section{ARGUMENT ZA JEDNODNEVNO PRAĆENJE BOLESNIKA S RAKOM}

Procjenili smo distribuciju bolesnika i kvantificirali putne troškove savjetovanja specijalista u liječenju raka. Od 1. do 31. listopada 2018. konzultirano je 2856 osoba s malignim bolestima, od toga 163 s rakom rektuma Putni troškovi iznosili su: $1,35 €$ po kilometru za one izvan Zagreba i 2,70€ za javni prijevoz onih u Zagrebu. Ukupni troškovi povratnog prijevoza u Zagrebu iznosili su 313,2€, dok je 21362,16€ koštao povratni prijevoz za bolesnike izvan Zagreba. Prosječna cijena po osobi i po dolasku iznosila je 132,98 €. Procjena za 2856 bolesnika je 379784,22 €.Troškovi prijevoza za one koji se savjetuju o njezi karcinoma predstavljaju značajan dio nepriznatih troškova u analizi sustava. Proces procjene troškova putovanja usputno prikazuje područje gravitiranja pacijenata prema centru za maligne bolesti. Oko 36\% bolesnika je iz Zagreba.

KLJUČNE RIJEČI: rak, troškovi prijevoza, praćenje

\section{INTRODUCTION}

Cancer incidence in Croatia is rising being over 22000 annually (1). Half of the patients who underwent surgery or chemoradiotherapy with curative intent while the other half will undergo palliative treatments or supportive care. In both scenarios, each diagnosed patient will be under surveillance: three to four times per year during the first two years, and then twice a year for the 
next three years. Usually, one or two specialists (surgeon/ oncologist/ nutritional support/ pain management) see the patient at those visits on a separate day, and the patient is required to bring along new laboratory exams, tumor markers and often ultrasound exam of the region most probably affected by recurrences or metastasis $(2,3)$. Some of these exams can be scheduled into one hospital visit, but at the moment the most common scenario is that patient needs at least three days to do all the required exams.

In 2015 we initiated One Day Clinic - a program for the diagnosis of breast cancer within one-day with the complete workup (4). The idea of one-day/one-stop diagnostics has been tested

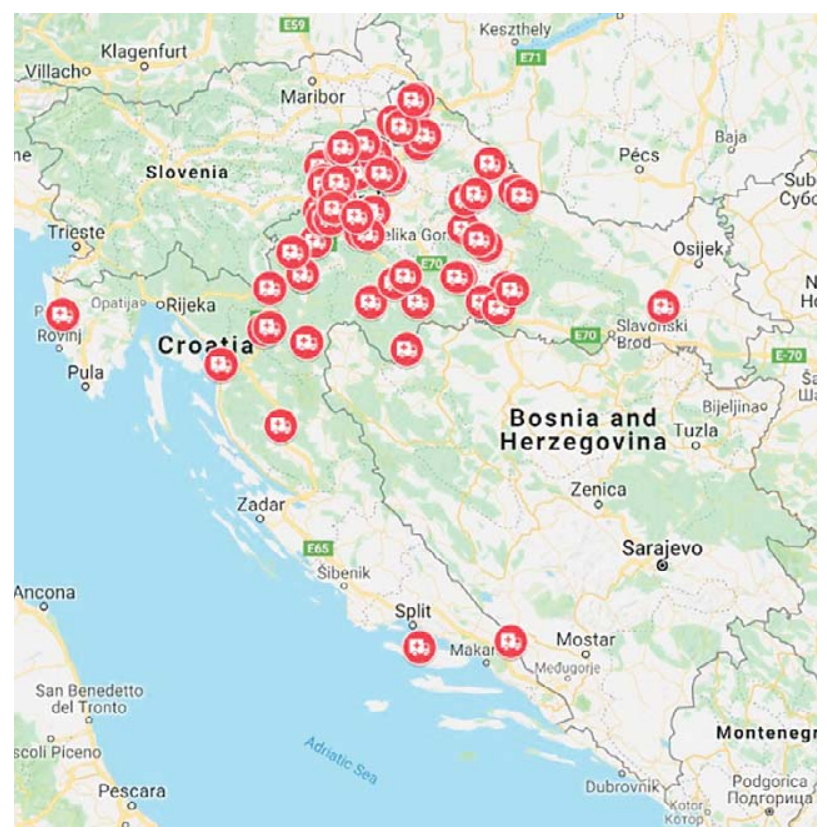

Figure 1. Distribution of patients consulted for rectal cancer in the outpatient clinic in one month period. mostly on breast cancer $(4,6)$ but has been tested on other cancers as well, for example, urological cancers (3). In 2015, Croatian Ministry of Health initiated a $72 \mathrm{~h}$ diagnostic scheme which improved the time track of cancer diagnostics during eight months it existed. Unfortunately, with the transition to the following government, the program was discontinued and was never evaluated in detail. However, during the execution of the Program, and One-day breast diagnostics we learned that with minor changes in the organization we gained a lot in timely diagnosis and in limiting early patients' distress when dealing with the diagnosis.

In case the patients could do the follow up within one day, through the one-day hospital, they would save two full days of their time (working days in some cases), plus the costs of transport and sick leave for those who work. From the hospital perspective, this would require adjustments of already existing slots for radiology exams and laboratory or a bit of extra work for the information technology department (IT department).

\section{MATERIALS AND METHODS}

To quantify the financial effect, we performed a simple calculus: we looked at the current outpatient consultancy flow. In October 2018, specialists consulted 5328 patients; 2856 patients with International Statistical Classification of Diseases and Related Health Problems (ICD-10) classification C diagnosis. Since we are a referral center for rectal cancer treatment, we decided to look at C20 diagnosis (which stands for rectal cancer). Specialists consulted 163 rectal cancer patients, of which 58 were from Zagreb and 95 were from other parts of

Table 1.

DEPICTS THE COST BASED ON THE COMPENSATION AVAILABLE FROM THE COUNTY HEALTH CENTER AND ESTIMATED PUBLIC TRANSPORT COSTS FOR THE CITY OF ZAGREB.

\begin{tabular}{|l|l|l|l|l|l|l|}
\hline Location & $\begin{array}{l}\text { Distance } \\
\text { in kilometers }\end{array}$ & $\begin{array}{l}\text { Number of consultations } \\
\text { (patients) }\end{array}$ & $\begin{array}{l}\text { Cost in euros* } \\
\text { one way }\end{array}$ & $\begin{array}{l}\text { Cost in euros* } \\
\text { return }\end{array}$ & $\begin{array}{l}\text { Cost in kunas** } \\
\text { one way }\end{array}$ & $\begin{array}{l}\text { Cost in kunas** } \\
\text { return }\end{array}$ \\
\hline Zagreb & 0 to 10 & $357(355)$ & 481,95 & 963,9 & 3570 & 7140 \\
\hline Minimal distance & 12 & & 16,2 & 32,4 & 120 & 240 \\
\hline Maximal distance & 457 & & 616,95 & 1233,9 & 4570 & 9140 \\
\hline Average distance & 83,2 & & 112,32 & 224,64 & 832 & 1664 \\
\hline Out of Zagreb & 12 to 457 & $163(154)$ & 18308,16 & 36616,32 & 135616 & 271232 \\
\hline
\end{tabular}

* calculated using $1 €=7.4 \mathrm{HRK}$

** reimbursement is 10 HRK per kilometer travelled 
Croatia. Patients receive a refund from their county for the travel expenses or cover the costs themselves in case they live in Zagreb (one-quarter of Croatian population lives in Zagreb). The refund is calculated as a roundtrip and varies from 8-10 HRK per kilometer (the equivalent of 1,08-1,35 $€$ ) depending on the resolution of the county which is in charge of the refund. Patients from the city of Zagreb are not refunded but are estimated to spend 20 HRK $(2,70 €)$ per visit, on public transport. We could not calculate the leave of absence because of the variable usage of the non-working option in cancer survivors.

\section{RESULTS}

The patients consulted for rectal cancer were mostly from the central part of Croatia with few exceptions gravitating away from their regional university hospital centers (Figure 1.).

\section{DISCUSSION}

Transportation of patients to specialist consultation is an excellent way to check on cancer center area of attraction and resources consumption of the system. In our patient sample, we quantified often disregarded aspect of care. The cost of the exams is covered by Croatian Health Insurance Fund and is constant in public medical services across Croatia so that it could have been omitted from the calculus. There is also no available data on waiting times within the premises for each exam patients need to perform. Furthermore, to catch the treatable recurrences or metastases we know will appear we need to have a more standardized follow-up and more comfortable for patients' compliance.

As a result, we believe that small interventions in the coordination of follow-up requirements would improve compliance and reduce the costs of the system. One solution has been implemented in one-day/one-stop diagnostic clinics for various cancer sites. Through our experience with one-day diagnostics and the experience of others $(1,4)$, the biggest challenge is changing the mindset of people involved in cancer care processes. Administrators at receptions and nurses often have to 'guide' patients from one stop in the diagnostic pathway to another.
The other option is merely using the technology for the follow up of patients living away from the hospital. Introduction of telephone/video calls as an official mean of coordinating diagnostics and delivering further treatment/surveillance guidance should be considered a valid alternative option. The pilots of these alternative processes are tested for continuous cancer care (8).

Finally, part of the cancer survivors care is transferred to general practitioners and systems of support when discharged from the hospital but communicating with specialists when needed: the term for this is aftercare. Despite being at the bottom of the European cancer survival scale, we still witness cancer becoming a chronic disease, and these steps are essential to rehabilitate the patients, treat the possible recurrences timely for them not to affect the overall survival.

Some services have to be delivered on site, while for others locally relevant online information could be the solution. Supportive care no longer comprises only of diagnostics: sexual dysfunctions, psychosocial effects, family and children support, rehabilitation and reintegration options need to be addressed as well. Respecting the patients' time by structuring and coordinated onestop initial aftercare might be the humane way to deliver all the information and ensure the compliance of the follow-up. A one-stop approach to surveillance should not compromise the quality of care based on one stop diagnostics experience $(5,6)$. To sum up, the landmark publication of the Institute of Medicine, Crossing the Quality Chasm, defines high-quality cancer care as effective, efficient, safe, patient-centered, timely and equitable (4). We used travel table to illustrated time, money and effort patients currently have to make for one consultation.

\section{CONCLUSION}

Transport cost for a patient being consulted on cancer care is a substantial part of not recognized costs in system analysis. The process of assessing travel costs display the area of gravitation toward a cancer center

\section{REFERENCES}

1. Croatian Institute for Public Health. Croatian National Cancer Registry. Cancer Incidence in Croatia 2015. Bulletin 2018;40. 
2. Available from: https://www.nccn.org/professionals/ physician_gls/pdf/breast.pdf accessed on 15th October 2018.

3. Available from: https://www.nccn.org/professionals/ physician_gls/pdf/rectal.pdf accessed on 15th October 2018.

4. Committee on Quality of Health Care in America, Institute of Medicine. Crossing the quality chasm: a new health system for the 21st century.National Academy Press Washington, DC 2001.

5. Coull N, Rottenberg G, Rankin S, Pardos-Martinez M, Coker B, Jenkins E, et al. Assessing the feasibility of a one-stop approach to diagnosis for urological patients. Ann R Coll Surg Engl. 2009;91:305-9.

6. Delaloge S, Bonastre J, Borget I, Garbay JR, Fontenay $\mathrm{R}$, Boinon $\mathrm{D}$, et al. The challenge of rapid diagnosis in oncology: Diagnostic accuracy and cost analysis of a large-scale one-stop breast clinic.Eur J Cancer. 2016;66: 131-7.

7. Ramljak V, Vielh F. One day diagnosis. Libri Oncol. 2014;1-3:83-5.

8. den Bakker CM, Schaafsma FG, Huirne JAF, Consten ECJ, Stockmann HBAC, Rodenburg CJ, et al. Cancer survivors' needs during various treatment phases after multimodal treatment for colon cancer - is there a role for eHealth? BMC Cancer. 2018;18(1):1207.

Corresponding author: Iva Kirac, Department of Surgical Oncology, University Hospital for Tumors, Sestre milosrdnice University Hospital Center, Ilica 197, Zagreb, Croatia.e.mail: iva.kirac@kbcsm.hr 